\title{
RESEARCH and EVALUATION
}

\section{Decentralisation, Participation and Boundaries of Transformation: Forest Rights Act, Wayanad, India}

\author{
Commonwealth Journal of Local Governance \\ Issue 12: May 2013 \\ http://epress.lib.uts.edu.au/ojs/index.php/cjlg
}

\author{
Sudheesh R. Chemmencheri \\ MA Development Studies \\ Department of Humanities and Social Sciences \\ Indian Institute of Technology, Madras
}

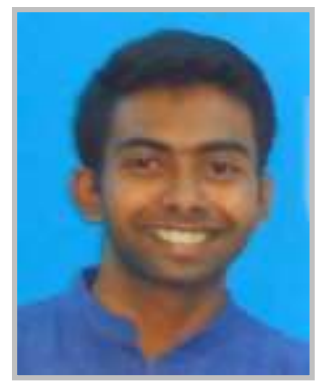

\begin{abstract}
Participation and decentralisation have been shown to yield democratic outcomes in terms of efficiency, accountability and transparency through citizen engagement and devolution of powers. It has been a matter of debate whether they also benefit marginalised communities like the indigenous peoples. This paper analyzes the implications of decentralised governance in a tribal zone in India using the case of the Scheduled Tribes and Other Traditional Forest Dwellers (Recognition of Forest Rights) Act 2006 - the Forest Rights Act. The effects of the Act are studied in the district of Wayanad, Kerala, through the theoretical framework of transformative decentralisation and spatial politics of participation. The key objectives of the Act - securing tenure and access to Minor Forest Producehave achieved limited success in Wayanad as a result of a narrowly construed ideas of people's participation. While the process prescribed by the Forest Rights Act has the potential to create new spaces for participation, most of these spaces remain closed in Wayanad. The absence of a larger vision and a radical motive to engage with the underlying patterns of domination and subordination in society has confined the process of decentralisation to its technocratic essentials, raising questions on the extent to which the Act can pave the way for transformation.
\end{abstract}

Keywords: Decentralisation, participation, indigenous communities, forest rights

\section{Acknowledgement}

I thank all the people of Wayanad who patiently conversed with me. I am grateful for the valuable guidance from Dr. Kalpana Karunakaran, and comments from Dr. Binitha V. Thampi,

Prof. Sudhir Chella Rajan, Dr. Prema Rajagopalan, Dr. Sudarshan Padmanabhan,

Dr. Uma Maheshwari, Aashish Gupta and Teena Augustine that helped shape this study. I also wish to thank the anonymous reviewers for their comments and suggestions. 


\section{Introduction}

Participation and decentralisation became popular themes with governments, civil society organisations and rights groups invoking the malleable meanings of these terms to demand better governance, based on the assumption that devolution of power and people's involvement in decisionmaking are yardsticks of good governance (Goulet 1989, Maro 1990). This good governance agenda was supported by the World Bank, which advocated decentralisation and participation as requisite for the success of both urban and rural development projects (World Bank 2000).

Evidence also emerged of the impact of participatory governance, especially in the fields of fiscal decentralisation (Smoke 2000), natural resource management (Gibson et. al. 2005) and urban governance (Bagchi and Chattopadhyay 2004). Communities were shown to be good managers of local resources by virtue of their local knowledge and their ease of rule-enforcement (Fizbein 1997). In the long term, local management was expected to promote a feeling of ownership of resources amongst the community (Ostrom 1990). Meanwhile, disparate colours of the politics of decentralisation have also emerged. For instance, Agrawal and Gupta (2005), based on their fieldnotes on the government-created user groups in Nepal's Terai protected areas, observe that the likelihood of participation was higher among the economically and socially well-off. In contrast, Krishna (2006) and Mattes (2008) reported from eastern India and South Africa respectively that spaces for participation are increasingly being taken up by the poor. Critiquing the transfer of responsibility of participation to the poor, Kothari (2001) highlights that it reifies the powerlessness of such people in the name of giving voice. Further, Williams et al. (2003) note that the overemphasis on participation at the lower strata of devolution of power occludes the simultaneous need for reform at the top.

The indigenous or tribal populations in India, also called adivasis (first inhabitants) or formally, Scheduled Tribes, have been economically, socially and politically marginalised during the precolonial, colonial and postcolonial times (Rao 1996). Any program to decentralise power in tribal areas, therefore, mandates careful scrutiny of its participatory effects that takes cognizance of the history of adivasi marginalisation. This study looks at a specific project of decentralisation, taking the instance of the Scheduled Tribes and Other Traditional Forest Dwellers (Recognition of Forest Rights) Act, 2006 (hereafter, the Forest Rights Act or the Act or the FRA), which seeks to devolve powers to elected institutions at the lowest level to facilitate the process of recognizing individual and community rights of the adivasis over forests. 


\section{Good Governance and Transformation}

Ribot et al.(2006, p. 1865) define decentralisation as 'any political act in which a central government formally cedes powers to actors and institutions at the lower levels in a political-administrative and territorial hierarchy.' When the process is confined to the setting up of new structures, it can be called deconcentration or administrative decentralisation. In contrast, political decentralisation involves downward accountability and is often legitimised through local elections (Ribot et al 2006).

\section{Technocratic versus transformative decentralisation}

Hickey and Mohan (2005, p.243) define technocratic decentralisation as 'reducing or smartening the central state, rather than as a political project aimed at transforming state legitimacy and forging a new contract between the citizens and the local state.' While technocratic governance is, of course, an essential feature of the bureaucratic model of administration, it does not go beyond its confines to engage deeply with society. In contrast, transformative decentralisation occurs where the governance model directly confronts oppressive social orders to spur change (Hickey and Mohan, 2004).

Participatory approaches in this framework are more likely to achieve successful outcomes where: (a) they are pursued as part of a wider radical political project confronting the existing structural arrangements and not just 'working around them'; (b) they are aimed specifically at securing citizenship and participation for marginal and subordinate groups; (c) the effort is not just to bring people to participate in the political process but to transform and democratise the political process itself so that the exclusionary tendencies of the process are allayed, and (d) they seek to engage with development as an underlying process of social change (Hickey and Mohan, 2004, p.168). The hope is that these efforts would help decentralisation move beyond its technocratic essentials.

\section{Participation as spatial practice}

Participation can be 'located' if it is looked at as a spatial practice (Cornwall 2004). Elaborating on how this could be developed into a useful framework, Cornwall writes:

Talking in terms of spaces for participation conveys 'the situated nature of participation', the
bounded yet permeable arenas in which participation is invited, and the domains from within
which new intermediary institutions and new opportunities for citizen involvement can be
fashioned. It also allows us to think about the ways in which particular sites come to be
populated, appropriated or designated by particular actors for particular kinds of purposes;
its metaphorical qualities allow attention to be paid to issues of discursive closure, to the
animation or domestication of sites for engagement, to the absence of opportunity as well as
to the dynamism of political agency in forging new possibilities for voice. 'By illuminating
the dynamics of power, voice and agency', thinking spatially can help towards building
strategies for more genuinely transformative social action (p.75).

Thus, the attempt in a successful participatory model should be to create new spaces that call for citizen engagement. Such spaces can take different forms depending on the complexity of interactions and the stakeholders involved. Cornwall (2004, p.80) derives from Lefebvre (1974) the understanding of space as 'a social product [that] is not simply there, a neutral container waiting to be filled, but is a 
dynamic, humanly constructed means of control and hence of domination, of power.' Cornwall suggests that spaces are defined by those who are invited into them as well as by those who do the inviting. These interactions form the germs of different forms of hierarchies and power relations.

Gaventa (2004) develops this concept further in formulating transformative participation as not just the right to participate in a given space but also the right to shape that space. An analysis of this would depend on 'how spaces are created, the places and levels of engagement, and the degree of visibility of power within them' (p.34). Gaventa suggests that there is a continuum of spaces which includes closed spaces (where decisions are made by a few behind closed doors), invited spaces (where citizen participation is invited with the explicit aim of widening consultations) and claimed or created spaces (that are won by the people from formal power structures). The different participatory spaces in a process exist 'in a dynamic relationship to one another, and are constantly opening and closing through struggles for legitimacy and resistance, co-optation and transformation' (p.35). This can lead to disparate outcomes. As the case-study would hint, two such possibilities are the inclusion of certain sections of the society while excluding the others, or the marginalised sections internalizing the dominant views and speaking the language of the dominant. In the case of postcolonial societies, these negotiations are complicated by the problem of institutional inertia. Heller (2001) discusses this problem in terms of the extent to which the bureaucracies have opened up to participation by subordinate groups. Decentralisation, in his framework, can be either technocratic, as discussed above, or anarcho-communitarian, which involves rejecting the authority of hierarchical structures and emphasizing the role of grassroots social movements in bringing about transformation. The trend towards a radical shift in the literature in an effort to salvage participation from becoming a mere chore is evident here.

\section{The Forest Rights Act}

\section{Decentralisation in tribal India}

The $73^{\text {rd }}$ and $74^{\text {th }}$ Constitutional Amendments inaugurated a new era of participatory governance in India in 1992 through the decentralisation of power. Part IX of the Indian Constitution titled 'Panchayats' was extended to the Scheduled Areas ${ }^{1}$ through the Panchayat (Extension to Scheduled Areas) Act (PESA), 1995, allowing for the creation of elected Panchayats (village councils) in tribal areas. Efforts were also made to decentralise forest management through Community Forest Management Programs and the much-discussed Joint Forest Management Program. But these programs were criticised for the limited participation of communities, persistent control by Forest Department (FD, the state machinery for forest governance) and entrenched local patriarchies (Agarwal 2001).

\footnotetext{
${ }^{1}$ Areas declared through Presidential declaration defined on the basis of population of tribal communities and economic standard of the people.
} 
The limitations of these programs cast doubt on the empowerment of tribal communities that the state sought to achieve. The tribals had been traditionally disadvantaged and marginalised by colonial as well as postcolonial forest policies (Guha 1983, Rao and Sankaran 2003, Bhatia 2005). On the one hand they had been subjected; on the other, they had internalised their identities as a classified, 'scheduled' community (Bose et. al. 2012).

In response to widespread campaigning by civil society organisations and tribal rights groups, the Scheduled Tribes and Other Traditional Forest Dwellers (Recognition of Forest Rights) Bill was introduced in Parliament on 15 December 2005. The Bill, drafted by the Ministry of Tribal Affairs, was passed on 18 December 2006. The Act was published in the Gazette of India only a year later on 31 December 2007.

\section{The FRA process}

The Act guarantees the tribal and other forest dwelling communities the rights to live, fish, extract Minor Forest Produce, graze animals, conserve forests and secure tenure including the right to convert patta (lease) from the government to titles. The Joint Parliamentary Committee, which considered the draft Bill for revision, emphasised the significance of the Bill stating that it was directly intended to fulfil the constitutional mandate under the Directive Principle of State Policy ${ }^{2}$ stated in Article 39(a), 39(b) and 46 of the Constitution. The structure of the FRA implementation authorities is pictured in Figure 1 below:

The FRA process starts with the most significant step of constituting the Forest Rights Committee (FRC) through elections by a neighbourhood group or Oorukoottam, which may contain people from the same tribe or different tribes. The FRC is thus constituted at a level lower to that mentioned in the Act, the level of the Grama Sabha ('village assembly', in which all adults in a Panchayat participate). The FRC facilitates the filing of claims by tribes for titles. A joint survey is then conducted by the Panchayat Forest Department and Revenue Department, and claims are finalised. These are then passed on to the Sub-Divisional Level Committee (SDLC) and then the District Level Committee (DLC) for approval and issuance of Records of Rights. Petitions against the decision of the FRC can be filed to the SDLC and those against the SDLC to the DLC. The DLC is the final authority on the Record of Rights.

\footnotetext{
${ }^{2}$ Directive Principles are strong recommendations from the Constitution that the State should aim to achieve, although they are non-binding. Article 39 (a) directs the State to secure livelihoods for men and women equally, Article 39 (b) directs the State to distribute the ownership and control of the material resources of the community such that it ensures common good and Article 46 directs the State to secure the educational and economic interests of the Scheduled Castes and Scheduled Tribes.
} 
Figure 1. Organisational structure of the FRA Institutions

Institution

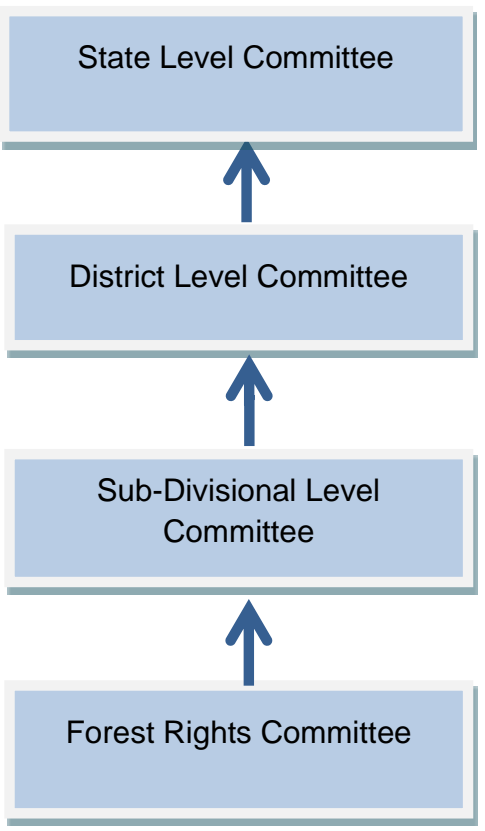

Composition

Chief Secretary, Revenue Secretary, Tribal Welfare Secretary, Forest Secretary, Panchayati Raj Secretary, Principal Chief Conservator of Forests, 3 Scheduled Tribe (ST) members of Tribal Advisory Council and Tribal Welfare Commissioner

District Collector, Deputy Commissioner, Divisional Forest Officer or Deputy Conservator of Forests, 3 members of District Panchayat (2 ST, 1 woman), Tribal Welfare Deputy Officer in charge of district

Sub-Divisional Officer, Forest Officer, 3 members of Block Panchayat (2 ST, 1 woman), Tribal Welfare Dept. Officer in charge of sub-division

10-15 members from the Oorukoottam, 1/3 ST, 1/3 women

The SDLC, the DLC and the State Level Monitoring Committee are composed of officials from the State Government's departments of Revenue, Forest and Tribal Affairs and three members of the decentralised institutions under the $73^{\text {rd }}$ Amendment, of whom two are ST members and at least one is a woman.

\section{Research Setting}

The experiences of the state of Kerala in decentralised governance have been commended around the world (e.g. Parayil 1996, Sen 1999, Véron 2000)ํ․ Heller (2001) presents Kerala as one of the exemplars of successful decentralisation, substantiating it with the case of the campaign for decentralised governance initiated by the State Planning Board and widely supported by the Communist Party of India (Marxist) or CPI(M) and the Kerala Shaastra Sahitya Parishad (Kerala Science Literature Movement). However, the marginalised communities have failed to benefit from these efforts or the reforms that the grassroots movements related to agrarian reforms and land distribution brought in (Steur 2009).

\footnotetext{
${ }^{3}$ Sen does not use the term 'model'. Véron distinguishes between an 'old' and a 'new' Kerala Model, the new one thrusting on participatory governance. The Kerala Model has, since then, been acerbically criticized. See for example Raman (2010).
} 


\section{Tribal land legislation in Kerala}

A number of land-related laws have been passed in Kerala, many of them having implications for the tribals (Table 1). The Kerala Land Reform Act, 1963, the pioneer legislation for land redistribution in the state, has been criticised for benefitting the non-tribals at the expense of tribals. Bijoy and Raman (2003) report incidents in which the non-tribal communities took tribal lands on short-term lease for cultivation and registered themselves as 'tenants' with the authorities. Later on, they claimed and obtained titles to the lands, dispossessing the tribal owner who had then become the 'landlord'.

Table 1: Tribal land-related legislation in Kerala

\begin{tabular}{|l|l|}
\hline 1963 & Kerala Land Reform Act 1963 \\
\hline 1972 & Kerala Private Forest (Vesting and Assignment) Act \\
\hline 1975 & $\begin{array}{l}\text { the Kerala Scheduled Tribes (Restriction on Transfer of Lands and Restoration of Alienated } \\
\text { Lands) Act }\end{array}$ \\
\hline 1999 & The Kerala Restriction on Transfer by and Restoration of Lands to Scheduled Tribes Act \\
\hline 2006 & Scheduled Tribes and Other Traditional Forest Dwellers (Recognition of Rights) Act of India \\
\hline
\end{tabular}

Most other laws brought out by the state government were also implemented with limited efficiency. In 1972, around 23,000 hectares of land was identified as part of the enactment of the Kerala Private Forest (Vesting and Assignment) Act, but the process was not completed. To reinstate the lands that adivasis lost to the others, the Kerala Scheduled Tribes (Restriction on Transfer of Lands and Restoration of Alienated Lands) Act, 1975 was passed with retrospective effect, holding all transactions of land during 1960-1982 as invalid and ordering the restoration of lands to the original owners. The Rules under the Act, which were published only a decade later, also prohibited transfer of lands from tribals to non-tribals. However, the adivasis had to pay compensation equivalent to the original sum received while selling the land, which could be paid by taking a loan from the government (to be repaid in 20 years, as allowed by the Act). This condition proved to be a disincentive for adivasis to reclaim their lands (Bijoy 1999). The Kerala Restriction on Transfer by and Restoration of Lands to Scheduled Tribes Act, 1999, on the other hand, held that encroachments of up to two hectares of land be condoned, jettisoning the need to restore alienated lands. For claims below two hectares, alternate land was to be given elsewhere. The new law was supported by all the major political fronts of Kerala who argued that the 1975 Act was unjust to the non-adivasi settlers (Bijoy 1999).

\section{Adivasi land struggles in Wayanad}

The adivasi struggles in Wayanad can be traced back to colonial times when some tribes like the Kurichyas formed armies to ward off the British invaders. More recent adivasi struggles were led by various political parties. The Karshaka Sangham (Farmers' Association) of the Naxalites protested against the policies of the state government in the late 1960s. In the 1980s and 90s other groups emerged such as the Adivasi Vikasana Pravarthaka Samiti (Tribal Development Work Forum), 
Adivasi Federation, Adivasi Aikya Samiti (Tribal Unity Forum), the Adivasi Kshema Samiti (Tribal Welfare Forum) etc.

The number of landless families in Wayanad region increased from 3,549 in 1976 to 22,491 in 2001, a seven-fold increase (Bijoy and Raman 2003). In July 2001, the Adivasi Dalit Samara Samiti (Tribal Protest Forum), led by C.K Janu and Geethanandan launched an intense struggle for adivasi rights. In August 2001, the Adivasi Gothra Mahasabha (AGMS, Tribal Grand Assembly) was formed by the same leaders, trying to reach an agreement with the state government. The agreement called for completing the process of land distribution between January 1 and December 31, 2002. The agreement included the promise of five acres of land to all adivasis having less than one hectare of land, and a tribal mission headed by officers of the Indian Administrative Service to oversee implementation of the agreement. The AGMS was spurred to react when it became evident that the government had diluted efforts to identify land and replaced the head of the tribal mission with a forestry official. In January 2003, adivasis led by the AGMS entered the Muthanga Wildlife Sanctuary in Wayanad to occupy land, following the government's failure to meet the deadline. In February 2003, the police clashed with the adivasis without prior warning, leading to the death of an adivasi and a policeman (Bijoy and Raman 2003). It is interesting to note that while land struggles in Wayanad have a rich history, there have been no separate struggles specifically for the Forest Rights Bill, unlike in the northern parts of the country where a strong tribal rights movement led the negotiations for enactment of the law.

\section{Research questions}

This study sought to answer three research questions:

1. To what extent has the inclusion and participation of tribes in decentralised governance fructified in Kerala, with a focus on securing of land titles?

2. How have the Forest Rights Committees used the powers under the Act?

3. What technocratic/transformative elements characterise the decentralisation process? The contextual relevance of these questions becomes obvious when it is noted that the Forest Rights Act has shifted the game of tribal land politics by vesting decision-making powers in the Forest Rights Committees constituted at the grassroots level. This stands in stark contrast to previous laws in the state, which were implemented in a top-down manner, positioning the tribals at the receiving end with little power to participate in the making or implementation of such laws. From a theoretical angle, the research questions explore what kind of spaces of participation - closed, invited or claimed - have been created following the FRA, and what limitations constrain the engagement of marginalised communities with a legal tool to transform the very process of participation. 


\section{Methodology}

This work is a qualitative study based largely on interviews conducted in Bathery and Mananthavady taluks (revenue divisions) of Wayanad District, Kerala, during March-April2012. The research setting was chosen for its significance to the history of adivasi land struggles in Kerala. Wayanad district is located at the heart of the Western Ghats $-17 \%$ of its population is tribal. The main adivasi communities are Paniya, Adiya, Kuruma, Kurichya, Kattunaaykka and Ooraali ${ }^{4}$. Wayanadan Chetty is an Other Traditional Forest Dweller community, not classified as a Scheduled Tribe, which lives mostly in the Manantavady Taluk. The respondents were chosen from a spectrum that represented the most important stakeholders in the implementation of the Forest Rights Act and included tribal leaders, Oorukoottam members and officials from the Tribal Development as well as Forest departments (Table 2). Of the 33 respondents, 27 belonged to tribal communities, while the others were government servants not from the Scheduled Tribes. Of these 27, nine were women, two of whom were activists for tribal rights issues.

Table 2: Profile of respondents ${ }^{5}$

\begin{tabular}{|l|c|l|l|}
\hline & Number & \multicolumn{1}{|c|}{ Tribe } & \multicolumn{1}{|c|}{ Gender } \\
\hline Adivasi Aikya Samiti activists & 2 & Kuruma, Kurichya & 1 Female, 1 Male \\
\hline Adivasi Gothra Mahasabha activist & 1 & Adiya & Female \\
\hline FRC Chairman & 1 & Paniya & Male \\
\hline Oorukoottam Members & 5 & Paniya & 2 Female, 3 Male \\
\hline Oorukoottam Members (FGD) & 15 & Kaattunaaykka & 5 Female, 10 Male \\
\hline FRA Awareness Class Instructor & 1 & Kuruma & Male \\
\hline Tribal Extension Officer & 1 & Adiya & Male \\
\hline Forest Watcher & 1 & Paniya & Male \\
\hline $\begin{array}{l}\text { Tribal Development Officers, Bathery and } \\
\text { Mananthavady }\end{array}$ & 2 & N/A & Male \\
\hline $\begin{array}{l}\text { Deputy Conservator of Forests (Civil Service } \\
\text { Position) }\end{array}$ & 1 & N/A & Male \\
\hline Forest Management Officer & 1 & N/A & Male \\
\hline $\begin{array}{l}\text { Former Representative to the state Legislative } \\
\text { Assembly }\end{array}$ & 1 & N/A & Male \\
\hline Founder-Activist of a local NGO & 1 & N/A & Male \\
\hline
\end{tabular}

The semi-structured conversations were conducted with an interview guide that asked questions in four categories: participation of all primary stakeholders; securing tenure; access to Minor Forest Produce and the role of the Forest Rights Committee and Panchayat. A focus group discussion was

4 The Paniya is the largest tribal community. Paniyas and Adiyas had been bonded laborers in the past. Kurumas and Kurichyas have traditionally owned some land and have cultivated on their own. Probably for the same reason, they have been relatively better off than the other tribes. The Ooraalis are largely farm laborers, potters or basket weavers. Kaattunaaykka is a community that still lives in close proximity to the forests, foraging.

${ }^{5}$ Under the Dept. of ST Welfare of the Govt. of Kerala, three Tribal Development Offices have been established in each of the three taluks of Wayanad district. The Tribal Development Officers chair these offices. Under each Tribal Development Office, multiple Tribal Extension Offices are also established to work in close proximity with the tribal communities. The Deputy Conservator of Forests and the Forest Management Officer belong to the Forest Department. The forest watcher is a person selected from the community by the Forest Department to keep surveillance of the forests. 
also conducted with around ten men and five women in a Kaattunaaykka settlement at Ponkuzhi located in Noolpuzha Panchayat in the Muthanga Wildlife Sanctuary. All conversations were conducted in Malayalam, audio-recorded with the informants' consent and transcribed. Secondary data were also collected from the Tribal Development Offices that included the Socio-Economic Survey of Scheduled Tribes in Wayanad 2008, the complete list of beneficiaries and titles secured under the FRA in Wayanad, and minutes of the Sub-Divisional Level Committee meetings. The names of the respondents quoted in this paper have been altered to protect their identity.

\section{Observations and Results}

The voices collected from the field bring out how the Act per se and its implementation are perceived by the different stakeholders. In general, all the interviewees agree that the Forest Rights Act is unprecedented in its content, but opinions do not always converge when it comes to the relevance of the Act in Wayanad, or the utility of the legislation in promoting participatory governance.

\section{Securing tenure}

Securing land titles is a key provision of the Act. There are no deadlines set for the FRA process to be completed, but the steps relating to making claims and surveying have been completed in Wayanad. The FRCs were thus constituted end in 2009. Table 3 shows the number of claims filed in Bathery Taluk:

Table 3: Number of claims for titles filed in Bathery Taluk

\begin{tabular}{|c|c|c|c|c|c|}
\hline Titles & Claims filed & $\begin{array}{c}\text { Passed by } \\
\text { FRC }\end{array}$ & $\begin{array}{c}\text { Passed by } \\
\text { SDLC }\end{array}$ & $\begin{array}{c}\text { Passed by } \\
\text { DLC }\end{array}$ & Granted \\
\hline Individual & 3537 & $\begin{array}{c}2973(84 \% \text { of } \\
3537)\end{array}$ & $\begin{array}{c}2406(68 \% \text { of } \\
3537)\end{array}$ & $\begin{array}{c}2328(65 \% \text { of } \\
3537)\end{array}$ & $\begin{array}{c}2212(62 \% \text { of } \\
3537)\end{array}$ \\
\hline Community & 201 & 0 & 0 & 0 & 0 \\
\hline
\end{tabular}

Source: Tribal Development Office, Bathery, 2012

Of the 3,537 individual claims filed, only $62 \%$ have been finally granted. From Table 3 , it can also be seen that although 201 community claims were filed before the FRCs, none has been given out. The Tribal Development Officers say that the surveys for community rights have yet to happen, but no timeline, not even a deadline, has been set to complete the process. This is in spite of the fact that community rights are a central provision of the FRA pertaining to the rights to graze, fish, collect forest products, protect traditional knowledge, maintain shrines and clear trees up to a maximum of 75 trees per hectare for development purposes (s.3 of the Act).

Acknowledgement of community rights has been one of the breakthroughs of the Act. In fact, what are labelled as 'community rights' have always been the very base of adivasi life:

Adivasis have never had the need to call the rights over commons by any particular term like community rights. I struggle to translate the English word to Malayalam while holding classes and convince them that there is a defined concept like this. 


\section{A C Radhakrishnan, FRA awareness class instructor}

In a random sample of 1,000 from the official list of beneficiaries from Bathery Taluk, the average land received by beneficiaries was found to be 0.115 hectares. The maximum size in the sample is 1.27 hectares, in spite of the FRA allowing the grant of land up to 4 hectares to each claimant family.

Only few people have actually got land. The land that has been given as part of the FRA equals nothing. This is a mockery of the Act.

Kannan, Adivasi Aikya Samiti

Withholding community rights and distributing paltry amounts of land hints at a level of hesitation amongst the bureaucracy in recognising adivasis as the rightful owners of their lands. The forests are still governed largely by the Forest Department. The designation of the Tribal Development Office as the nodal agency for implementing the Act - imposed under the assumption that tribals cannot get just treatment under the Forest Department - has not really been fruitful here.

The way that land titles have been distributed also hints at the existence of fractures within the tribal community. While the major political parties have their own adivasi members, the major one being the Communist Party of India (Marxist) backed Adivasi Kshema Samiti, there are some groups who oscillate between the power camps. Some others, like Adivasi Gothra Mahasabha, have chosen to stay away from political influences. Then there are the isolated tribal forums and NGOs mostly working on social welfare aspects of tribal life. One such organisation, the Adivasi Aikya Samiti, has been involved in spreading awareness on the Act:

We have been speaking for adivasi rights. The CPI(M)-led struggles for land titles have benefitted only their followers.

Amala, Adivasi Aikya Samiti

This leads to the question of representation - who speaks for the adivasis and how. Although there are leaders from within the adivasi communities, many of them lose their independent position and get co-opted into the mainstream political parties. Political mainstreaming in itself cannot be judged as either good or bad, but where the mainstreaming of marginalised communities is involved, the discussion warrants a closer look at the history of the mainstream parties' engagement with communities.

Even if new leaders emerge from the adivasi community, they are immediately taken by the political parties into their fold. Given the background of poverty that most of these young leaders come from, they are forced to be taken in, expecting some benefits in future. Even those who come up to better positions develop a mainstream outlook and do not look back or think of doing anything for their community.

Janani, Adivasi Gothra Mahasabha

These trends have constrained the efforts to spread awareness about the FRA, allowing them limited success. A few classes were held on the basic procedures of the Act by educated volunteers and NGOs, though a large part of the community remains unaware of the provisions of the Act: ask where to file a claim and how to go about it, but say that they won't be able to fight for it. 
Poverty occupies their time. They can fight an elephant in the forest, but not the shrewdness of officials.

A C Radhakrishnan, awareness class instructor

The implementation of the Forest Rights Act could have been an opportunity to unite all the fragmented adivasi groups and trigger a new movement for land rights. But participation of the adivasis even in the technocratic process has been severely undermined by several constraints, including poverty, migration and cultural beliefs:

Many adivasis are migrant laborers in Kodagu. In many places, surveys were conducted when they were not at home. Adivasis who live deep inside the forests get no benefits at all.

Amala, Adivasi Aikya Samiti

There are some communities who are nomadic and do not understand the concept of settling down with titles.

\section{Access to Minor Forest Produce}

Tribal Extension Officer, Bathery

Access to Minor Forest Produce (MFP) is another significant provision of the Act. Clause 3 (1) (a) of Chapter II of the Act grants 'the right of ownership, access to collect, use, and disposal of minor forest produce which has been traditionally collected within or outside the village boundaries'. Clause 2(1)(d) of the Rules under the Act delineate that the disposal of minor forest produce shall include local level processing, value addition, transportation in forest area through head-loads, bicycle and handcarts for use of such produce or sale by the gatherer or the community for livelihood.

However, adivasis continue to be denied permission to access products from their own forests. Products like gooseberries, medicinal plants, honey etc., which have been collected by the adivasis traditionally, have formed a major part of the FD's revenue, leading to a lack of willingness on their part towards relinquishing those rights:

The Forest Department still controls the forest. The societies for the sale of forest products also have the presence of a Forest Department officer. Earlier they could even brew their own liquor. Now, that's also prohibited

Tribal Development Officer, Mananthavady taluk

While the involvement of adivasis in forest monitoring is put forth as a progressive step by the Forest Department, the Department has been widely criticised for controlling the sale of MFPs through agencies called 'societies' created by the Department to carry out the sale of MFPs collected by the tribals. The lack of any wide movement, unlike in many other parts of the country, further constrains the 'liberation' of MFPs from state control:

The minimum wages for procured MFPs is only around 75 rupees in place of an expected 125 rupees. That too, only those who are members in the societies set up by the FD can sell it to them.

Amala, Adivasi Aikya Samiti

The voices from the field also clearly record the powerlessness that the tribals feel towards the FD in spite of the latter being bureaucratic machinery that so closely interacts with their lives:

It's not like earlier. The foresters shoo us away now. It's not like earlier. 
Ramakrishnan, Kaattunaaykka community, Panavally

No one goes for work these days. The Foresters do not let us in much.

Maathan, Kaattunaykka community, FGD, Ponkuzhi

The foresters say there will be a forest fire. So we are not let in.

Maaran, Kaattunaaykka community, FGD, Ponkuzhi

\section{The role of the Forest Rights Committee}

In Wayanad, the Forest Rights Committees are constituted at the level of the Oorukoottams (hamlets), which are smaller than the Grama Sabhas. Ideally, an Oorukoottam should be the assembly of all adult men and women in a neighbourhood, discussing issues relating to their lives and enabling interaction with the Panchayat. There are both Oorukoottams that are uniformly encompassed of the same tribal community as well as those that have a mix of different tribal and/or non-tribal communities. While the concept of the Oorukoottam is old, the current ones were recently created:

The whole tradition of Oorukoottams has been subverted in Wayanad. The new ones and the FRCs are formed by whichever political party is in power in the Panchayat. Persons favored by the party are planted as FRC members.

Janani, Adivasi Gothra Mahasabha

To elect an FRC, the Panchayat and the Scheduled Tribe Promoters (frontline officers from the Tribal Extension Officers catering to the daily needs of adivasis like distribution of welfare benefits, transportation to hospitals etc.) seek representation from the neighbourhood, one-third of whom are supposed to be women. This assurance itself does not prove the level of participation that happens at the FRC meetings. As per the FRA procedure, in an Oorukoottam assembly, the adivasis raise their claim over a piece of land that they consider belongs to them before the FRC. The FRC records the claims and then listens to the claimants on how they were the traditional dwellers on the land before the cut-off date of 13 December 2005 (as mentioned in the Act), based on various factors such as presence of a shrine or revered tree or any relevant official document. The FRC then grants the verified claims and sends them to the higher committees for revision. The requirement that adivasis have to claim the land and prove that they have been the traditional dwellers necessitates that the adivasis take the onus of establishing ownership. While forums like the Adivasi Aikya Samiti have guided the adivasis through the FRA process, this is an isolated instance. The very structure of the FRA hierarchy is done in such a way that the Panchayat has only cursory role in the FRA process, making the FRA hierarchy almost a parallel structure. While the benefit of this arrangement is noninterference in the FRC's decisions, the downside is the absence of any institutional support to awareness building.

The FRA process and the Grama Panchayat have no major connections. The Panchayat Secretary is supposed to oversee the proceedings of the Forest Rights Committee, that's all.

Tribal Extension Officer, Sultan Bathery 
While the original intention of this arrangement can be proffered as autonomy for the Forest Rights committee, there is no check to make sure that an actual participatory assembly of all the men and women in the neighbourhood is held. The risk of participation becoming symbolic is, therefore, high.

As for the tribals, they just understand the Panchayat as a place to ask for schemes. Usually the general Grama Sabha is held in the morning, and the ST topics are discussed in the afternoon. Naturally attendance drops.

Tribal Development Officer, Mananthavady

\section{The process of decentralisation}

Table 3 showed that while the number of individual claims filed before the FRC in Bathery Taluk is 3,357 , the number of claims granted have been chopped down at successive levels in the FRA hierarchy, i.e. the Sub-Division Level Committee, the Block Level Committee and the District Level Committee. No explanations have been accorded for the denial of titles. Participation, as has been shown in the previous section, occurs minimally. The Oorukoottams are not held regularly, and draw only a token number of people. Participation does not go beyond attending a few FRC meetings and filing claims. The contrast between the following two voices is noteworthy:

The survey to verify the claim for land titles is done jointly by the Panchayat, Revenue Department and Forest Department. The Forest Department does GPS mapping and the information is stored in a database.

Forest Management Officer, Sultan Bathery

The adivasis never get to participate in the survey process, or know what the officials have done.

Janani, Adivasi Aikya Samiti

The result is that a veil is created between the technical process and the adivasis. Surveying, which forms the most important step in recognizing and granting the Record of Rights, thus becomes an essentially technocratic activity. What is generally lacking is a will to use FRA as a tool for societal transformation:

The general attitude of the Forest Department is not to give an inch of land to the adivasis. With the coming of the FRA, the FD is under immense pressure to grant land.

Tribal Development Officer, Mananthavady

The comment by the Tribal Development Officer sheds light on how the different departments perceive each other. The Tribal Development Office, in fact, is closer to the adivasis in that they implement various schemes related to tribal welfare. But the one aspect of adivasi life that they do not have jurisdiction on is the forests. Also, the Panchayat, Forest Department, Revenue Department and the Tribal Development Offices continue to work in their own closed circles.

These results, while juxtaposed with the long history of adivasi land struggles that the district has seen, raise some disquieting questions. The FRA appears not to have 'sunk into' the minds of the adivasis and the officials alike as they have failed to see the immense transformative potential of the Act. Adivasi communities in Kerala, unlike their counterparts in the north and central regions of 
India, ${ }^{6}$ were not involved in any separate struggle asking for the Act or demanding its implementation. As a consequence, the FRA became just another piece of legislation sent out to the state administration from New Delhi to be executed with a new set of bureaucratic machinery.

The FRA was envisaged to be a larger project reversing the historic injustice to adivasis and ushering in an era of justice through recognition of rights. It is to be underlined that this is not merely a onetime scheme or project for distribution of land titles but constitutionally recognised legislation that recognises ownership of land and resources as a right. However, progress on the implementation of the Act in Wayanad shows a performance that is diluted and weak.

The FRA has been thoroughly subverted. From 'forest rights', it has been shrunken to mere 'title rights'. If all adivasis get land and start farming, they would rise above poverty by themselves. Everyone needs food. Thus, everyone is a part of this struggle. But the moment adivasis fight for forests, it is branded as an "adivasi struggle" repelling others away from it.

Janani, Adivasi Gothra Mahasabha

\section{Theoretical Understanding - Boundaries of Transformation}

\section{Technocracy or transformation?}

It could be inferred from the field notes that there is no larger vision associated with the FRA process as far as its implementation in Wayanad is concerned. It has not even been recognised as a part of the land reforms movement for which Kerala is known, the benefits of such reforms confined only to nontribal communities. The state is also generally known for the degree to which issues are politicised and fought out through democratic discourse. In the Wayanad case, however, the mainstream political parties seem to have missed the case of adivasis, although attempts to give symbolic positions to adivasi members are still ongoing. Regardless of the political background of the government, the adivasi cause was repeatedly sidelined through exclusionary legislation on land reforms, although the parties have always used the adivasis as an electoral group.

The FRA process in Wayanad has not yet been a tool to confront fragmentations within the adivasi society or a method to create a level playing field for the adivasis to interact with the Forest Department and other state machineries. The existing hierarchies, therefore, continue to exist. In the absence of an express willingness to deal with the underlying social dynamics and stratifications, the spirit of transformative decentralisation remains undermined. The institutions created as part of the decentralisation process under the FRA depend in part on the same forest bureaucracy that has failed to secure land rights for the adivasis. This impedes any effort in transforming the very process of decentralisation. In the absence of NGOs or adivasi forums actively fighting for the FRA or monitoring its implementation, there are no checks in place to ensure the due process. There is no explicit emphasis on deepening citizenship and social inclusion under a comprehensive agenda of

\footnotetext{
${ }^{6}$ Many of these NGOs came together to form the forum called Campaign for Survival and Dignity in New Delhi. There are 150 organisations affiliated to the Campaign currently.
} 
empowerment, except for granting a paper document that proves the possession of a few cents of land in the hands of the few adivasis who got land. Such an agenda should commence with the acknowledgement that the adivasi's relationship with the forest, forest management and ensuring social justice can all be made part of the same project.

\section{Spatial politics of the FRA}

The Wayanad story demonstrates how political negotiations and governance, technocratic or transformative, play out in the specialised context of forests. The Forest Rights Act can thus easily be 'located', to use Cornwall's (2004) terminology. The adivasi voices clearly reverberate with the centrality of the forests in their lives and how their histories are tied with the history of colonisation and post-colonial state control over forests. However, it also emerges that the agency of the adivasis to engage with, and own, the space is limited to filing claims and cursory FRC meetings thereby depriving them of their right to shape the space. The surveys undertaken as part of the FRA process, on the other hand, create robust databases on adivasi lands using the latest technology. This risks the FRA being just another machinery of state control indicating a tendency towards recentralisation through decentralisation. The examination of the roles of the different stakeholders showed how the physical space came to be appropriated by particular actors for specific purposes. The adivasis, the key stakeholder in the process have received little role in this space.

Considering the situated nature of participation under the FRA, although the provision for the creation of FRCs was supposed to create an 'invited space' for citizen consultation, these spaces still remain closed on the ground. All adult members of the community were supposed to come together to register their claims, discuss community rights and make their demands at the FRC. However, the functioning of the FRCs has mostly remained slapdash. The spaces for participating in the survey processes and understanding how the distribution of land is done have also remained closed. The different episodes of the adivasi struggles in the past did create 'claimed spaces' for negotiations with the state. However, the fact that the FRA has not figured in such negotiations limits the viability of such claimed spaces in facilitating a discussion on forest rights. The forest space has thus been coopted thoroughly into the technocratic machinery. The result is that the adivasis choose to stay away from any of these intersecting spaces and retire to their usual lives, relinquishing their rights to change the way the space with which their existence is bound is shaped. In the absence of a larger movement from the adivasi community to demand the implementation of the FRA, the question of representation remains problematic. The fragmented adivasi community is represented by a few voluntary organisations that have not yet taken up the FRA as a key project. 


\section{Conclusion}

Understanding forest rights in its complexity can only be facilitated if there is an inherent project of respecting indigenous rights and recognising diversity. The Forest Rights Act, in its formulation, has given abundant opportunities to bring in such a project to fruition while simultaneously creating a meaningful structure for devolution of powers. Lack of a wider political project, absence of a unified campaign by the adivasi forums, fragmentation within the community, devolution of powers in the design of the decentralisation program to authorities with a history of indifference towards the tribals and lack of awareness regarding the potential of the legislation emerge as the main constraints from this case study. Transformation cannot occur as a part of the structure itself, it must be brought in through actual (and not symbolic) participation by creating open and invited spaces, the onus of which has to be taken by the state and the community concurrently.

\section{References}

Agarwal, B. (2001) Participatory Exclusions, Community Forestry and Gender: an Analysis of South Asia and a Conceptual Framework. World Development, 29 (10), 1623-1648

Agrawal, A. and Gupta, K. (2005) Decentralisation and Participation: the Governance of Common Pool Resources in Nepal's Terai. World Development, 33(7), 1101-1114

Bagchi, S. and Chattopadhyay, S. (2004) Decentralised Urban Governance in India: Implications for Financing of Urban Infrastructure. Economic and Political Weekly, 39(49), 5253-5260

Bhatia, B. (2005) Competing Concerns. Economic and Political Weekly , 40(47), 4890-4893

Bijoy, C.R. (1999) Adivasis Betrayed: Adivasi Land Rights in Kerala. Economic and Political Weekly, 34(22), $1329-1335$

Bijoy, C.R. and Raman, K. R. (2003) Muthanga: the Real Story. Economic and Political Weekly, 38(20), 19751982

Bose, P; Arts, B. and van Dijk, H. (2012) Forest Governmentality: A Genealogy of Subject-Making of ForestDependent Scheduled Tribes in India. Land Use Policy, 29(3), 664-673

Cornwall, A. (2004) Spaces for Transformation? Reflections on Issues of Power and Difference in Participation in Development. In: S. Hickey and G. Mohan (eds.), Participation: from Tyranny to Transformation. New York: Zed Books, 75-91

Fizbein, A. (1997) The Emergence of Local Capacity: Lessons from Colombia. World Development, 25(7), $1029-1043$

Gaventa, J. (2004) Towards Participatory Governance: Assessing the Transformative Possibilities. In: S. Hickey and G. Mohan (eds.), Participation: from Tyranny to Transformation. London, New York: Zed Books, 25-41

Gibson, C. C.; Williams, J. T. and Ostrom, E. (2005) Local Enforcement and Better Forests. World Development, 33(2), 273-284

Goulet, D. (1989) Participation in Development: New Avenues. World Development, 17(2), 165-178

Guha, R. (1983) Forestry in British and post-British Era. Economic and Political Weekly, 18(44), 1882-1896

Heller, P. (2001) Moving the State: The Politics of Democratic Decentralisation in Kerala, South Africa and Porto Alegre. Politics and Society, 29(1), 131-163

Hickey, S and Mohan, G. (2004) Relocating Participation within a Radical Politics of Development: Insights from Political Action and Practice. In: S. Hickey and G. Mohan (eds.), Participation: from Tyranny to Transformation. New York: Zed Books, 159-174 
Hickey, S and Mohan, G. (2005) Relocating Participation within a Radical Politics of Development. Development and Change 36(2), 237-262

Kothari, U. (2001) Power, Knowledge and Social Control in Participatory Development. In Cooke, B. and Kothari, U. (eds.) Participation: the New Tyranny? London: Zed Books

Krishna, A. (2006) Poverty and Democratic Participation Reconsidered: Evidence from the Local Level in India. Comparative Politics 38(4), 439-458

Larson, A. M. and Soto F. (2008) Decentralisation of Natural Resource Governance Regimes. Annual Review of Environment and Resources, 33, 213-39

Lefebvre, H. 1974 (1991). The Production of Space. London: Verso. Cited in Cornwall, A. (2004) Spaces for Transformation? Reflections on Issues of Power and Difference in Participation in Development. In: S. Hickey and G. Mohan (eds.), Participation: from Tyranny to Transformation. New York: Zed Books, 75-91

Maro, P. S. (1990) The Impact of Decentralisation on Spatial Equity and Rural Development in Tanzania. World Development, 18(5), 673-693

Mattes, R. (2008) South Africans' Participation in Local Politics and Government. Transformation: Critical Perspectives on Southern Africa 66/67, 117-141

Ostrom, E. (1990) Governing the Commons. Cambridge: Cambridge University Press

Parayil, G. (1996) The 'Kerala Model' of Development: Development and Sustainability in the Third World. Third World Quarterly, 17(5), 941-957

Raman, R. (2010) Development, Democracy and the State: Critiquing Kerala Model of Development. New York and London: Routledge

Rao, B. J. (1996) Adivasis in India: Characterisation of Transition and Development. In: T.V. Satyamurthy ed., Region, Religion, Caste, Gender and Culture in Contemporary India. New Delhi: Oxford University Press, 417-443

Rao, R.K. and Sankaran, S.R.(2003) Forest Myths, Jungle Laws and Social Justice. Economic and Political Weekly, 38(46), 4819 - 4821

Ribot, J. C.; Agrawal, A. and Larson, A.M. (2006) Recentralizing while Decentralizing: How National Governments Reappropriate Forest Resources. World Development, 34(11), 1864-1886

Sen, A. (1999) Development as Freedom. Oxford: Oxford University Press

Smoke, P. (2000) Strategic Fiscal Decentralisation in Developing Countries: Learning from Recent Innovations. In: S. Yusuf, W. Wu and S. Evenett (eds.), Local Dynamics in an Era of Globalisation. Oxford: Oxford University Press, 101-109.

Steur, L. (2009) Adivasi Mobilisation: 'Identity' versus 'Class' after the Kerala Model of Development? Journal of South Asian Development, 4(1), 25-44

Véron, R. (2000) The 'New' Kerala Model: Lessons for Sustainable Development. World Development, 29(4), 601-617

Williams, G., Srivastava, M., Corbridge, S. and Véron, R. (2003) Enhancing Pro-Poor Governance in Eastern India: Participation, Politics and Action Research. Progress in Development Studies, 3(2), 159-178

World Bank (2000) World Development Report 1999/2000. Washington D.C: World Bank 